\title{
Chronic Effect Various Type of Exercises to Fasting Blood Glucose and Insulin Resistance
}

\author{
Yetty Machrina $^{1^{*}}$, Ambrocious Purba ${ }^{2}$, Dharma Lindarto ${ }^{3}$, Milahayati \\ Daulay $^{4}$ \\ ${ }^{1,3,4}$ University of Sumatera Utara \\ ${ }^{2}$ Padjajaran University
}

\begin{abstract}
Exercise is non-pharmacological management for Diabetes Mellitus (DM) type-2. Previous study found that both eerobic and interval training improved insulin resistance. The aim of this study was to analyze the chronic effect various type of exercises to fasting blood glucose (FBG) and insulin resistance in DM type-2 model rats. It was an experimental study, twenty male Wistar rats, age 8 weeks, weight $150-180$ gram as the object. Rats were given high fed diet for 4 weeks then injected streptozocin dose $30 \mathrm{mg} / \mathrm{kgBB}$ in citrate buffer $\mathrm{pH}$ 4.5 i.p, and $45 \mathrm{mg} / \mathrm{kgBB}$ at the following week. Groups were divided into i.e moderate continous training (MCT), severe continous training (SCT), slow interval training (SIT), and fast interval training (FIT). All groups were treated with ran on the treadmill three times a week for 8 weeks. Fasting blood glucose and fasting insulin were checked before and after intervention. Insulin resistance was determined by calculating HOMA-IR. Data analized with paired t-test $(p<0,05)$. The results shown that all group significantly decreased fasting blood glucose and insulin resistance $(\mathrm{p}<0,05)$ after eight weeks exercise except insulin resistance in MCT group. Fasting blood glucose and insulin resistence post-test was found lowest in SIT groups in this study. In conclucions chronic effect of aerobic continous and aerobic interval in various intensity can decrease fasting blood glucose and insulin resistance in DM type-2 rat model. Slow interval training was the best exercise model to decrease insulin resistance.
\end{abstract}

Keyword: Exercise, Blood Glucose Level, Insulin Resistance, DM Type-2, Rat

Abstrak. Latihan adalah manajemen non-farmakologis untuk Diabetes Mellitus (DM) tipe2. Penelitian sebelumnya menemukan bahwa baik pelatihan eerobic dan interval meningkatkan resistensi insulin. Tujuan dari penelitian ini adalah untuk menganalisis efek kronis berbagai jenis latihan untuk glukosa darah puasa $(F B G)$ dan resistensi insulin pada tikus model DM tipe-2. Itu adalah penelitian eksperimental, dua puluh tikus Wistar jantan, usia 8 minggu, berat 150-180 gram sebagai objek. Tikus diberi diet makan tinggi selama 4 minggu kemudian disuntikkan streptozocin dosis $30 \mathrm{mg} / \mathrm{kgBB}$ di buffer sitrat $\mathrm{pH} 4,5$ i.p, dan $45 \mathrm{mg} / \mathrm{kgBB}$ pada minggu berikutnya. Kelompok-kelompok dibagi menjadi pelatihan kontinu sedang (MCT), pelatihan berkelanjutan yang berat (SCT), pelatihan interval lambat (SIT), dan pelatihan interval cepat (FIT). Seтиa kelompok diobati dengan berlari di treadmill tiga kali seminggu selama 8 minggu. Glukosa darah puasa dan insulin puasa diperiksa sebelum dan sesudah intervensi. Resistensi insulin ditentukan dengan menghitung HOMA-IR. Data dianalisis dengan paired t-test $(p<0,05)$. Hasil menunjukkan bahwa semua kelompok secara signifikan menurunkan glukosa darah puasa dan resistensi insulin ( $p$

${ }^{*}$ Corresponding author at: Faculty of Medicine, Universitas Sumatera Utara, Medan, Indonesia 
$<0,05)$ setelah delapan minggu latihan kecuali resistensi insulin pada kelompok MCT. Berpuasa glukosa darah dan resistensi insulin post-test ditemukan terendah dalam kelompok SIT dalam penelitian ini. Dalam conclucions efek kronis interval aerobik terus menerus dan aerobik dalam berbagai intensitas dapat menurunkan glukosa darah puasa dan resistensi insulin pada model DM tipe-2 tikus. Latihan interval lambat adalah model latihan terbaik untuk menurunkan resistensi insulin.

Kata Kunci:

Latihan, Tingkat Glukosa Darah, Resistensi Insulin, DM Tipe-2, Tikus

Received [23 October 2017] | Revised [30 May 2019] | Accepted [31 May 2019]

\section{Introduction}

Exercise is recommended for patient with diabetes mellitus (DM) type-2. Previous study has proved that exercise could reduce insulin resistance in diabetes mellitus type-2 patients [1]. The chronic effects of exercise can improve insulin receptor sensitivity, insulin signaling, and impaired skeletal muscle mitochondrial dysfunction [2].

Improvement of insulin sensitivity was characterized by decreasing HOMA-IR and fasting blood glucose. During exercise skeletal, muscle contraction activated myogen protein kinase (AMPK) enzyme in mitochondria which is master switch in metabolism, as a marker of energy cell status. This enzyme is activated by reduction of ATP/keratin fosfat ratio. AMPK facilitated GLUT-4 translocate to surface membrane so that plasma glucose can move into cell although insulin secretion suppressed [3]. Meanwhile exercise adaptation to neural and hormonal response during exercise stimulated insulin receptor up regulation. Insulin signaling enhance and mitochondrial biogenesis improve due to increase PGC-1 $\alpha$ gene expression [3], [4].

Aerobic training can be continous or interval. Previous study shown either continous training or interval training can lead fasting blood glucose (FBG) decline in DM type-2 patients, increased insulin sensitivity and insulin signaling protein [5]. However, few studies found that interval training better than continous training in increasing insulin sensitivity especially high intensity interval training.

Patients with DM type-2 were suggested to aerobic continous, moderate to severe intensity, 3 times a week, 30 - 60 minute per session [6]. Nevertheless based on previous study, adherence of type 2 DM in exercising without supervise still very low [7]. It was associated to feel saturated and fatique during exercise [8]. Exercise intermitten interval interspersed with a recovery phase with lower intensity between exercises give patient spare time to short break before continouing exercise. 
The aim of this study was to analyze the chronic effect various type of exercises in various intensity to fasting blood glucose (FBG) and insulin resistance (HOMA-IR) in DM type-2 model rats.

\section{Methodology}

It was an experimental study with pretest and post-test design. Twenty male wistar rats, aged 8 weeks, weight 150-180 gram were used in this study. Rats were acclimated for 7 days, eat and drink were given adlibithum followed by high fed diet for 4 weeks. Then all rats injected with streptozocin (STZ) dose $30 \mathrm{mg} / \mathrm{kgBB}$ in citrate buffer $\mathrm{pH} 4.5$ intraperitoneal and dose 45 $\mathrm{mg} / \mathrm{kgBB}$ at the following week. A week after STZ administration, FBG and HOMA-IR was checked. Rat was declared as DM type-2 model when FBG was $>200 \mathrm{mg} / \mathrm{dl}$. DM type-2 rats model divided into 4 groups, i.e moderate continous training (MCT), severe continous training (SCT), slow interval training (SIT) and fast interval training (FIT).

\section{Exercise Protocol}

Rats get used to run on treadmill for 3 days. Beginning with a light intensity speed of $15 \mathrm{~m} / \mathrm{min}$ for 15 minutes. Speed and duration were increased gradually $15 \mathrm{~m} / \mathrm{min}$ for 20 minutes and $20 \mathrm{~m} / \mathrm{min}$ for 20 minutes.

When all groups had familier with treadmill, exercise protocol were begun.

MCT group ran on treadmill speed $20 \mathrm{~m} /$ minutes for 30 minutes.

SCT group ran on treadmill speed $24-33 \mathrm{~m} /$ minute for 30 minutes

SIT group ran on treadmill speed $20 \mathrm{~m} /$ minute, $10 \times 2$ minute/1minute recovery periode FIT groups ran on treadmill speed $30 \mathrm{~m} /$ minute, $15 \times 30$ second $/ 1$ minute recovery periode All exercise protocols in each group were held 3 times a week for 8 weeks.

\section{FBG AND HOMA-IR EXAMINATION}

FBG and fasting insulin were examined before and after exercise protocol ( 8 weeks). Blood serum was collected from vein tail. FBG was examined with photometer while fasting insulin was examined by ELISA methode. Insulin resistance determined as HOMA-IR. HOMA-IR was calculated with formula:

fasting insulin (mIU/L)x fasting blood glucose (mg/dl) 405 


\section{DATA ANALYSIS}

Fasting blood glucose (FBG) and HOMA-IR pre-test and post-test difference were analized by paired t-test with significant level was $\mathrm{p}<0,05$.

\section{Results}

Afer second low dose STZ injection, FBG for each group can be seen at Table 1. The influence of 8 weeks exercise to FBG alteration for each group can be seen from Table 2. The alteration of insulin resistance due to 8 weeks exercise can be seen at Table 3 .

Table 1 The average of FBG before and after induction of STZ

\begin{tabular}{llllll}
\hline \multirow{2}{*}{ Groups } & \multicolumn{3}{c}{ Before } & \multicolumn{5}{l}{ After } & \multirow{2}{*}{$p$ value } \\
\cline { 2 - 5 } & $\begin{array}{l}\text { Mean } \\
(\mathrm{mg} / \mathrm{dl})\end{array}$ & SD & $\begin{array}{l}\text { Mean } \\
(\mathrm{mg} / \mathrm{dl})\end{array}$ & $\mathrm{SD}$ & \\
\hline MCT & 111 & 26 & 339 & 103,7 & $0,004^{*}$ \\
SCT & 127,6 & 7,3 & 398,2 & 25,1 & $0,000^{*}$ \\
SIT & 129,2 & 6,9 & 452,6 & 31,3 & $0,000^{*}$ \\
FIT & 125,2 & 6,9 & 451,2 & 83,2 & $0,001^{*}$
\end{tabular}

$\mathrm{SD}=$ standard deviation, $\mathrm{MCT}=$ moderate continous training, $\mathrm{SCT}=$ severe continous training, $\mathrm{SIT}=$ slow interval training, $\mathrm{FIT}=$ fast interval taining

Table 1 shown that the average of FBG before STZ injection were equal among groups. FBG all groups after STZ injection became $>200 \mathrm{mg} / \mathrm{dl}$, indicated that all groups have become diabetic type-2 rats model.

Table 2 FBG all groups after 8 weeks exercise

\begin{tabular}{llllrll}
\hline Group & $\begin{array}{l}\text { Pre-test } \\
\text { Mean } \\
(\mathrm{mg} / \mathrm{dl})\end{array}$ & SD & $\begin{array}{l}\text { Post-test } \\
\text { Mean } \\
(\mathrm{mg} / \mathrm{dl})\end{array}$ & SD & FBG reduction & P value \\
\hline MCT & 339 & 103,7 & 191,6 & 55,4 & 147,4 & $0,014^{*}$ \\
SCT & 396,8 & 25,1 & 198,2 & 75,0 & 198,6 & $0,009^{*}$ \\
SIT & 452,6 & 31,3 & 227,2 & 87,8 & 225,4 & $0,001^{*}$ \\
FIT & 451,2 & 83,2 & 259 & 125,0 & 192,2 & $0,006^{*}$ \\
\hline
\end{tabular}

(*) significant. $\mathrm{SD}=$ standard deviation, MCT $=$ moderate continous training, $\mathrm{SCT}=$ severe continous training, $\mathrm{SIT}=$ slow interval training, FIT $=$ fast interval taining. $\mathrm{FBG}=$ fasting blood glucose

Table 2 shown that all type of exercises statistically significant decreased FBG. The highest reduction of FBG after 8 weeks exercise was found in SIT.

Table 3 HOMA IR all groups after 8 weeks exercise

\begin{tabular}{lllrrrl}
\hline Groups & $\begin{array}{l}\text { Pre test } \\
\text { Mean }\end{array}$ & SD & $\begin{array}{l}\text { Post test } \\
\text { Mean }\end{array}$ & SD & \multicolumn{1}{l}{$\begin{array}{l}\text { HOMA- } \\
\text { IR } \\
\text { reduction }\end{array}$} & $\begin{array}{l}\text { P } \\
\text { value }\end{array}$ \\
\hline MCT & 1631,7 & 727,1 & 767,3 & 155,0 & 864,33 & 0,061 \\
SCT & 1463,7 & 109,1 & 333,6 & 115,6 & 1130,17 & $0,000^{*}$ \\
SIT & 1692,3 & 380 & 298,5 & 71,1 & 1393,77 & $0,001^{*}$ \\
\hline
\end{tabular}




\begin{tabular}{lllllll}
\hline FIT & 1640,4 & 584,8 & 353,8 & 140,1 & 1286,54 & $0,004 *$ \\
\hline
\end{tabular}

(*) significant. $\mathrm{SD}=$ standard deviation, $\mathrm{MCT}=$ moderate continous training, $\mathrm{SCT}=$ severe continous training, $\mathrm{SIT}=$ slow interval training, FIT = fast interval taining. HOMA-IR= homeostasis assessment of insulin resistance

Table 3 was shown that insulin resistance was significantly difference before and after 8 weeks exercise among SCT, SIT and FIT $(p<0.05)$ except MCT group. The lowest insulin resistance post-test was shown in SIT group.

\section{Discussion}

Increasing Insulin receptor sensitivity was characterized by a decreased insulin resistance caused by improvement of insulin receptor signaling in skeletal muscle, liver and adipose tissue. Insulin and exercise were the most physiological appropriate stimulator for glucose transported. Exercise could improved insulin sensitivity by increasing GLUT- 4 translocation, mitochondrial enzyme, and modified fast glycolitic fibers (tipe II) became slow glycolitic fibers (tipe I). Chronic effects of exercise increase PGC1 $-\alpha$ gene activity resulting in improved mitochondrial function in patients with type 2 diabetes mellitus [9]. Mitochondria and substrate transporters play an important role in the oxidative metabolism of substrate muscles that can decrease insulin resistance [10].

Exercise can lead to change cytosolic messenger activity such as Ca2+ and AMP in human and mice, which result in activation of signaling cascade and eventually to alteration in GLUT -4 gene and mitochondrial gene ekspression. It has been suggested that AMPK activates the PGC-1 $\alpha$ coactivator, which promoted the expression of other transcription factors of the slow glycolysis fibers9. Chronic adaptation of exercise result enhancement insulin receptor density at the skeletal muscle membrane. It can lead better enhancement of insulin signalling promoted GLUT-4 translocation to cell membrane surface.

Our recent study found that all exercise model can decrease fasting blood glucose (Table 2) and insulin resistance (Table 3). Seems that there were dose response relationship between intensity and both parameter decline. Interval training was better than continuous to reduce plasma blood glucose and insulin resistance. This study was also found that slow interval training has lowest blood glucose and insulin resistance level than the other models after 8 weeks exercise.

Aerobic interval training can promote insulin sensitivity better than moderate intensity continuous training if compared with baseline data insulin receptor phosphorylation, receptor signalling, and PGC-1 $\alpha 4$. Exercise with recovery periode between exercises (intermitten interval) give the individual short break time before resuming the exercise with a predetermined intensity. Although previous study found that high intensity better than low intensity to enhance insulin sensitivity [11], but in current study slow interval training was shown the lowest FBG reduction and insulin 
resistance. Suggested minimalized fatique and board during exercise for certain duration time, can influence adherens to do exercise for maintain stable blood glucose level.

Deflation insulin resistance in moderate continous training was not statistically significant. This might be related to the time of exercise. Eight weeks of exercise has not quite enough to change insulin resistance significantly in MCT.

\section{Conclusion}

Both continuous training and interval training in various intensity can reduce FBG and insulin resistance in DM type-2 rat model. Aerobic interval especially Slow Interval Training can be recommended for Diabetes type-2 patient as exercise model to reduce fasting blood glucose and insulin resistance.

\section{REFERENCES}

[1] R. J. Sigal et al., "Effects of aerobic training, resistance training, or both on glycemic control in type 2 diabetes: a randomized trial," Annals of internal medicine, vol. 147, no. 6 , pp. 357-369, 2007.

[2] K. I. Stanford and L. J. Goodyear, "Exercise and type 2 diabetes: molecular mechanisms regulating glucose uptake in skeletal muscle," Advances in physiology education, vol. 38, no. 4, pp. 308-314, 2014.

[3] J. Evans, The Secret Life of Mitokondria, vol. 1st Eng. ed. San Francisco: Exclusive patented, 2009.

[4] R. E. R. Rocha et al., "Interval training attenuates the metabolic disturbances in type 1 diabetes rat model," Arquivos Brasileiros de Endocrinologia \& Metabologia, vol. 57, no. 8, pp. 594-602, 2013.

[5] A. E. Tjønna et al., "Aerobic interval training versus continuous moderate exercise as a treatment for the metabolic syndrome: a pilot study," Circulation, vol. 118, no. 4, pp. 346354, 2008.

[6] A. D. Association, "Standards of medical care in diabetes - 2015 abridged for primary care providers," Clinical diabetes: a publication of the American Diabetes Association, vol. 33, no. 2, p. 97, 2015.

[7] P. Soewondo, "Current practice in the management of type 2 diabetes in Indonesia: Results from the International Diabetes Management Practices Study (IDMPS)," Journal of the Indonesian Medical Association, vol. 61, no. 12, 2012.

[8] K. Karstoft et al., "Mechanisms behind the superior effects of interval vs continuous training on glycaemic control in individuals with type 2 diabetes: a randomised controlled trial," Diabetologia, vol. 57, no. 10, pp. 2081-2093, 2014.

[9] J. Ntanasis-Stathopoulos, J. G. Tzanninis, A. Philippou, and M. Koutsilieris, "Epigenetic regulation on gene expression induced by physical exercise," J Musculoskelet Neuronal Interact, vol. 13, no. 2, pp. 133-46, 2013.

[10]D. Hoshino, Y. Kitaoka, and H. Hatta, "High-intensity interval training enhances oxidative capacity and substrate availability in skeletal muscle," The Journal of Physical Fitness and Sports Medicine, vol. 5, no. 1, pp. 13-23, 2016.

[11]J. A. Babraj, N. B. Vollaard, C. Keast, F. M. Guppy, G. Cottrell, and J. A. Timmons, "Extremely short duration high intensity interval training substantially improves insulin action in young healthy males," BMC endocrine disorders, vol. 9, no. 1, p. 3, 2009. 